\title{
An evaluation of the dietary habits of English programme medical students in their first year of studies
}

\section{Ocena nawyków żywieniowych anglojęzycznych studentów pierwszego roku medycyny}

\author{
Aleksandra Gawlikowska-Sroka ${ }^{\circledR}$, Edyta Dzięciołowska-Baran', Jacek Szczurowski², \\ Magdalena Szałowska-Bojarun ${ }^{3}$ \\ 1Pomorski Uniwersytet Medyczny w Szczecinie, Katedra i Zakład Anatomii Prawidłowej i Klinicznej, al. Powstańców Wlkp. $72,70-111$ Szczecin \\ Pomeranian Medical University in Szczecin, Department of Anatomy \\ 2 Uniwersytet Przyrodniczy we Wrocławiu, Zakład Antropologii, ul Kożuchowska 5, 51-631 Wrocław \\ Wroclaw University of Environmental and Life Sciences, Department of Anthropology \\ ${ }^{3}$ Corecta Gabinety Rehabilitacji i Terapii Dziecięcej, ul. M. Niedziałkowskiego 26A/1, 71-410 Szczecin \\ Corecta Clinic of Children' Rehabilitation and Therapy \\ $\checkmark$ gawlikow@pum.edu.pl
}

\begin{abstract}
Introduction: Human nutrition depends on many factors. Cultural practices, socio-psychological and economic factors play important roles in development of correct nutrition patterns. Eating habits are formed most strongly during childhood and adolescence. When young people begin university study, their way of life changes significantly. In this study group, not only do the necessities of independent living and food preparation occur, but also a change the country of residence.

The aim of the study was to investigate the dietary habits of medical students of the English programme.

Materials and methods: The material consisted of data collected from an anonymous survey distributed among 1st year students of the Faculty of Medicine and Dentistry ( 28 men and 52 women). The study used a questionnaire consisting of open and multi-choice questions concerning the anthropometric data of subjects and principles of nutrition. Data were analysed statistically.
\end{abstract}

\section{ABSTRAKT}

Wstęp: Sposób odżywiania człowieka zależy od wielu aspektów. Bardzo duże znaczenie w przypadku jego kształtowania się mają zwyczaje kulturowe, czynniki społeczno-psychologiczne i ekonomiczne. Zwyczaje żywieniowe najsilniej formują się w okresie dzieciństwa i młodości. Podjęcie studiów zmienia sposób życia wielu młodych osób. W analizowanym przypadku większość studentów stanęła nie tylko przed koniecznością usamodzielnienia się poprzez samodzielne mieszkanie, przyrządzanie posiłków, ale również zmiany kraju zamieszkania.

Celem pracy była ocena nawyków żywieniowych anglojęzycznych studentów medycyny.

Materiały i metody: Materiał badawczy stanowiły dane pochodzące $\mathrm{z}$ anonimowej ankiety zebranej pośród studentów I roku wydziału lekarskiego i lekarsko-stomatologicznego (studiów anglojęzycznych), wypełnionej przez 28 mężczyzn oraz 52 kobiety. Do badań wykorzystano kwestionariusz ankiety własnego autorstwa, składający się z pytań otwartych i pytań wyboru dotyczących danych antropometrycznych badanych osób i zasad odżywiania. Kwestionariusz opracowano na podstawie międzynarodowego, standardowego kwestionariusza $\mathrm{z}$ badań nad zachowaniami zdrowotnymi młodzieży szkolnej - Health Behaviour in School-Aged Children (HBSC). Dane opracowano statystycznie.
Results: Obesity was generally not observed in the group of examined students. In most cases body mass index (BMI) remained in the normal range. Cases of obesity were observed only among the men. There were no significant differences between the men and women in terms of the regularity of meals. About $50 \%$ of the study population declared a regular consumption of 3 main meals a day. Significantly more women than men followed slimming diets. We did not observe significant differences between men and women in terms of activities concerned with controlling weight. Significantly more women than men had fruits and vegetables every day. Men more often consumed sweets, coffee and fast-food. Analysis of the results showed abnormal patterns in the quality and quantity of meals. Conclusions: It is essential to introduce measures in the field of nutrition education into the curriculum in order to shape appropriate patterns of healthy nutrition among future doctors and thus prevent lifestyle diseases caused by inappropriate dietary habits. Keywords: nutrition; lifestyle; health promotion.

Wyniki: W grupie badanych studentów nie zaobserwowano występowania problemu otyłości. W większości przypadków wskaźnik BMI (body mass index) utrzymywał się w granicach normy. Przypadki nadwagi częściej obserwowano u mężczyzn. Nie stwierdzono istotnych różnic pomiędzy grupami mężczyzn i kobiet w częstości regularnego spożywania posiłków. W ciągu tygodnia studenci odżywiają się nieregularnie. Tylko ok. 50\% badanej populacji deklaruje regularne spożywanie 3 podstawowych posiłków. Kobiety istotnie częściej od mężczyzn stosują diety odchudzające. Nie stwierdzono istotnych różnic pomiędzy przedstawicielami obu płci w podejmowaniu działań mających na celu kontrolę masy ciała. Kobiety istotnie częściej deklarują codzienne spożywanie owoców i warzyw. Mężczyźni częściej spożywają słodycze, kawę i produkty typu fast-food. Analiza wyników wykazała nieprawidłowe wzorce w strukturze spożywanych posiłków.

Wnioski: Stwierdzono nieprawidłowe wzorce w jakości i ilości spożywanych posiłków. Studenci nie stosują zasad zdrowego odżywiania w codziennym życiu. Istotne jest wprowadzanie działań z zakresu edukacji żywieniowej do programu studiów w celu kształtowania wśród przyszłych lekarzy prawidłowych wzorców prozdrowotnych i zapobiegania chorobom cywilizacyjnym. Słowa kluczowe: odżywianie; styl życia; promocja zdrowia. 


\section{INTRODUCTION}

The concept of health fields was coined in 1973 by Lalonde [1] to suggest that lifestyle has the greatest impact (55\%) on human health. The impact of other fields is less prominent: environment $-20 \%$, biology and genetics $-15 \%$, and health care organization $-10 \%$. Unhealthy behaviours not only reduce the quality of life and deteriorate the health of individuals, but also affect the social environment [2].

Proper nutrition is one of the most important determinants of normal growth, sexual maturation, physical activity and mental state. Human nutrition depends on many factors. Cultural practices and socio-psychological and economic factors play an important role in the development of correct nutrition patterns. Eating habits are formed most strongly during childhood and adolescence. When many young people begin university study, it changes their way of life significantly. In this study group, not only do the necessities of independent living and food preparation occur, but also a change in the country of residence. In Poland and many other countries, obesity is becoming an increasingly important problem, especially in children and adolescents $[3,4,5]$. Nutritional mistakes made during rapid growth and maturation can cause many metabolic disorders. The development of obesity is accompanied by an increased prevalence of metabolic syndrome, diabetes mellitus, ischaemic heart disease and atherosclerosis. Studies carried out in Sudan showed that about $50 \%$ of obese students have metabolic syndrome [6]. The problem of an increasing number of patients with metabolic syndrome has also been reported in Japan [7]. Recent years have seen a growing problem of hypertension in children in Italy [8]. More and more negative trends in nutrition have also been observed among children and adolescents in Poland $[3,4,5,9,10]$. Moreover, there is a high rate of mortality from cardiovascular diseases in the adult population. The World Health Organization predicts that by 2020, 2-3 of all diseases in the world will be caused by poor lifestyle [11], formed mainly at a young age and then affecting health in later life [3,4]. Among adolescents, poor eating patterns, reflected in an insufficient number of meals or incorrect quantity and quality of food, have been reported for many countries worldwide, including the UK [12, 13], Sudan [6], China [14], Spain [15], Australia [16], and USA [17]. Overeating is often used as a means of coping with stress [5], and a reduced number of meals is usually caused by constant haste and a lack of properly shaped nutrition patterns, which are normally determined by social and psychological factors (level of education, level of knowledge), demographics such as social origin, family size, place of residence, economic status (family income) or lifestyle, cultural practices and individual preferences [13, 18]. Low physical activity, sedentary behaviours and poor diet quality can lead to poor mental health [19, 20]. Many young people who begin university study change their living environment and have to become self-reliant. During this period of numerous changes and stress associated with new challenges, it is important to strengthen positive patterns and promote a healthy lifestyle $[13,21,22]$.
The aim of the study was to investigate the dietary habits, including type of meals, their frequency, regularity and composition, of I year English programme students of medicine and dentistry in Poland.

\section{MATERIALS AND METHODS}

The material consisted of data collected from an anonymous survey distributed among I year students of the Faculty of Medicine and Dentistry ( 28 men and 52 women). Most of the students came from Norway and Sweden, and a single person from Germany. The mean age was 20.5 years. The study used a questionnaire of our own design, based on a standard HBSC survey (Health Behaviour in School-Aged Children: A WHO Collaborative cross-national study) [23], the Goldberg scale GHQ-12 (General Health Questionnaire) [24], and the Huebner scale (Student's Life Satisfaction Scale) [25]. The survey included open and multi-choice questions.

Results are presented in contingency tables. The significance of differences in the frequencies of the different variants of answers in sex groups was analysed using Pearson's $\chi^{2}$ test, the most popular test of significance for qualitative variables. Where the test showed a significance of differences in frequencies, the differences between the observed and expected values in the individual fields of the table were also analysed. Yates' correction was used to prevent overestimation of statistical significance for small data.

Body mass index (BMI) was presented in the form of basic statistics separately for each sex. The significance of differences in mean BMI in the analysed groups was assessed using the t-Student test for independent variables, after previous analysis for the equality of variances in groups using the $\mathrm{F}$ Fisher test. The level of significance was adopted at $\mathrm{p}<0.05$.

\section{RESULTS}

The analysis of the collected data showed normal BMI values in the majority of respondents. There was a significantly higher number of overweight men than women $(\mathrm{p}<0.05)$. Obesity was not identified in any of the groups (Fig. 1).

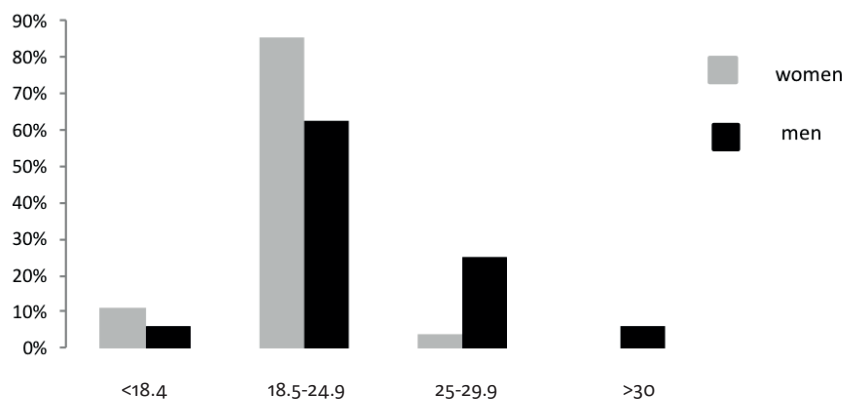

FIGURE 1. Body mass index 
Proper nutrition depends not only on the quantity and quality of consumed food, but also on the number of meals. One of the key questions of the survey addressed this aspect of diet. Only $50 \%$ of the surveyed population declared regular consumption of 3 basic meals - breakfast, lunch and dinner. Men had evening snacks significantly more often $(\mathrm{p}<0.05)$. No significant differences between men and women were found for other meals (Fig. 2).

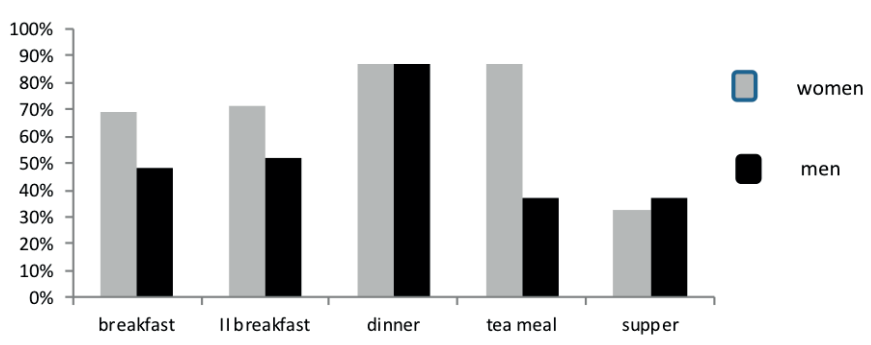

FIGURE 2. Regularity of meals

There were significant differences between men and women in terms of consumed food types. Women significantly more often had fruits (Pearson's $\chi^{2}: 7.02032, \mathrm{df}=1, \mathrm{p}=0.008060$ ) and vegetables (Pearson's $\chi^{2}$ : 4.07392, $\mathrm{df}=1, \mathrm{p}=0.043553$ ), as well as milk and dark bread (Fig. 3). On an everyday basis, men significantly more often had chocolate and other sweets (Pearson's $\left.\chi^{2}: 3.93684, \mathrm{df}=1, \mathrm{p}=0.047242\right)$, fast-food and carbonated drinks (Pearson's $\chi^{2}: 10.0137, \mathrm{df}=1, \mathrm{p}=0.001554$ ) and coffee.

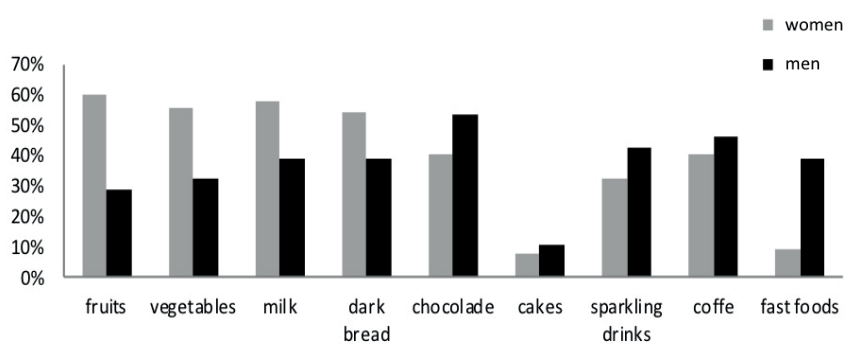

FIGURE 3. Structure of food

Special diets (sliming, vegetarian, high-protein, low-carb and low-calorie) were popular among students. More women than men followed slimming diets (Pearson's $\chi^{2}: 3.76319, \mathrm{df}=$ $1, \mathrm{p}=0.052395)$.

\section{DISCUSSION}

Studies on the lifestyle of children and adolescents conducted in many countries have revealed alarming results. For example, a clear global trend in negative behavioural patterns has been observed: bad eating habits, reduced physical activity, and also increased consumption of stimulants such as alcohol, tobacco and other psychoactive substances. [13, 26, 27, 28, 29, 30]. An increasing proportion of children and adolescents are overweight or obese [8]. Our survey revealed that only $50 \%$ of students regularly consume basic meals, i.e. breakfast, lunch and dinner during the week and at weekends. Similar findings were made in studies carried out among students of the Medical University in Łódź [2], Szczecin [10] and Białystok [31]. Most surveyed students had irregular meals, and often skipped breakfasts in their everyday diet [31]. Studies conducted in the UK found a close relationship between the regularity of meals, particularly breakfast, and physical activity. A higher number of more active subjects had regular 4-5 meals a day, including breakfast, which may prove the respondents' awareness of healthy behaviours [12]. Our survey conducted in a group of English-speaking students revealed an alarmingly low consumption of fruit and vegetables, also reported by other authors [16]. Less than $50 \%$ of students include these important products in their everyday diet. What is more, about 35-40\% of them have fast-food, sweets and carbonated drinks daily. A similar trend was observed in Australia [16]. Studies on models of nutrition have also shown increased consumption of coffee among adolescents. Our survey of the English-speaking student population indicated that coffee consumption was lower than in similar studies conducted in Japan [7].

One of the survey questions addressed the use of special diets. Low-calorie diets were most popular in the analysed group of students. Interestingly, none of the respondents indicated the Norwegian diet, despite the fact that most of them come from Norway and other Scandinavian countries. Similar results were obtained from a survey among Polish-speaking students [10]. Women are more consistent in maintaining their diet, keeping dietary recommendation and consumption of recommended daily amount of vegetables [32].

Most students who begin their university education change dietary habits by changing their place of residence. The respondents analysed in our study had moved to Poland, which, although not very distant from Scandinavia, has different culinary traditions. Research carried out in various student groups worldwide has shown that, in general, young people lack skills in preparing meals. The extensive curriculum of the chosen difficult discipline of studies also reinforces negative behavioural patterns, which is reflected in irregular meals, their reduced number, and lower quality of consumed food [18]. In all countries, surveys among students have shown that negative eating habits often coexist with a reduced level of physical activity and the use of stimulants [2, 9, 13]. For example, research conducted in Norway at the University of Tromso showed a close positive correlation between increased physical activity and increased bone density, and a negative correlation between bone density and cigarette smoking [33]. Our study, despite the identified poor nutrition and low physical activity, did not reveal any significant deviations in BMI among the 
surveyed students. Most respondents had normal BMI values, but more men than women were overweight or obese.

Similar observations were made in Saudi Arabia, where the problem of obesity among adolescents is becoming a challenge for public health [34], and among adolescents in Pakistan, where an increased incidence of type 2 diabetes was reported [35]. Unfortunately, all surveys conducted among Polish adolescents studying at universities have shown nutritional mistakes, low levels of physical activity, and an increase in the use of stimulants $[9,10,29,30,36]$. Negative health behaviours are most common among students of technical universities, while those studying medical sciences and biology-related disciplines had higher awareness and more often showed healthy behaviours [2, 29, 30, 31]. Generally, students who endorsed healthy aesthetic factors (health, effect on physical appearance, freshness) as important for food, presented a healthy style of eating [17].

The problem of unhealthy lifestyle in a group of future doctors is important, not only because of the effect on their later life and health, but also in the context of their influence on their future patients. Negative health behaviours among medical professionals should be eliminated as much as possible $[21,35,37]$, and students should be educated in a healthy lifestyle and know how to pass on these principles to patients. Medical students participating in courses on healthy lifestyle run at Harvard University changed their behaviour for better, and also showed greater concern about the lifestyle of their patients [37]. The introduction of lifestyle medicine into the mandatory curriculum for medical students was discussed at the meetings of deans, lecturers and students from medical universities in 2013 and 2014 organised in Boston [21]. Participants in these meetings identified the key areas of focus, namely actions to increase the level of physical activity among students and change poor nutritional habits, which require the support of university authorities responsible for planning educational strategies. An online, cross-sectional survey in the UK showed that University policy to improve students' diets should incorporate efforts to promote student engagement in cooking and food preparation, and increased availability of low cost healthier food items [13]. Promotion of an active lifestyle in childhood may prevent both internalizing and externalizing disorders during adolescence [19] and could improve the mental health and well-being of students [20].

\section{CONCLUSIONS}

The specific work environment of physicians requires elimination of negative health behaviours. A trustful relationship between the patient and the doctor cannot be established if the patient can see unhealthy behaviours in their doctor [2]. Therefore, students from the early days of their medical studies have to be educated in healthy lifestyles and learn, for example, about the principles of proper nutrition.

\section{REFERENCES}

1. Lalonde M. A New Perspective on the Canadians: a working document. Ottawa: Minister of Supply and Services Canada; 1974.

2. Łaszek M, Nowacka E, Gawron-Skarbek A, Szatko F. Negatywne wzorce zachowań zdrowotnych studentów. Część II. Aktywność ruchowa i nawyki żywieniowe. Probl Hig Epidemiol 2011;92(3):461-5.

3. Chrzanowska M, Kozieł S, Ulijaszek SJ. Changes in BMI and the prevalence of overweight and obesity in children and adolescents in Cracow, Poland, 1971-2000. Econ Hum Biol 2007;5(3):370-8.

4. Woynarowska B, Małkowska-Szkutnik A, Mazur J, Kowalewska A, Komosińska K. School meals and policy on promoting healthy eating in schools in Poland. Med Wieku Rozwoj 2011;15(3):232-9.

5. Mazur J, Dzielska A, Małkowska-Szkutnik A. Psychological determinants of selected eating behaviours in adolescents. Med Wieku Rozwoj 2011;15(3):240-9.

6. Yasir HE, Tahir OA, Leena BM, Imam SN. Metabolic syndrome and its association with obesity and lifestyle factors in Sudanese population. Diabetes Metab Syndr 2016;10(3):128-31. doi: 10.1016/j.dsx.2016.01.002.

7. Morinaka T, Wozniewicz M, Jeszka J, Bajerska J, Nowaczyk P, Sone Y. Westernization of dietary patterns among young Japanese and Polish females - a comparison study. Ann Agric Environ Med 2013;20(1):122-30.

8. Menghetti E, Strisciuglio P, Spagnolo A, Carletti M, Paciotti G, Muzzi G, et al. Hypertension and obesity in Italian school children: The role of diet, lifestyle and family history. Nutr Metab Cardiovasc Dis 2015;25(6):6027. doi: 10.1016/j.numecd.2015.02.009.

9. Poręba R, Gać P, Zawadzki M, Poręba M, Derkacz A, Pawlas K, et al. Styl życia i czynniki ryzyka chorób układu krążenia wśród studentów uczelni Wrocławia. Pol Arch Med Wew 2008;118(3):1-9.

10. Gawlikowska-Sroka A, Dzięciołowska-Baran E, Szczurowski J. Ocena nawyków żywieniowych studentów polskich pierwszego roku medycyny. Pomeran J Life Sci 2015;61(2):186-90. doi: 10.21164/pomjlifesci.77.

11. Chopra M, Galbraith S, Darnton-Hill I. A global response to a global problem: the epidemic of over nutrition. Bull World Health Organ 2002;80(12):952-8.

12. Corder K, van Sluijs EM, Ridgway CL, Steele RM, Prynne CJ, Stephen AM, et al. Breakfast consumption and physical activity in adolescents: daily associations and hourly patterns. Am J Clin Nutr 2014;99(2):361-8. doi: 10.3945/ajcn.111.027607.

13. Sprake EF, Russell JM, Cecil JE, Cooper RJ, Grabowski P, Pourshahidi LK, et al. Dietary patterns of university students in the UK: a cross-sectional study. Nutr J 2018;17(1):90. doi: 10.1186/s12937-018-0398-y.

14. Du SS, Jiang YS, Chen Y, Li Z, Zhang YF, Sun CH, et al. Development and applicability of an internet-based diet and lifestyle questionnaire for college students in China: a cross-sectional study. Medicine (Baltimore) 2015;94(49):e2130. doi: 10.1097/MD.0000000000002130.

15. Navarro-Prado S, González-Jiménez E, Montero-Alonso MA, López-Bueno M, Schmidt-RioValle J. Life style and monitoring of the dietary intake of students at the Melilla campus of the University of Granada. Nutr Hosp 2015;31(6):2651-9. doi: 10.3305/nh.2015.31.6.8973.

16. Scully M, Morley B, Niven P, Crawford D, Pratt IS, Wakefield M. Factors associated with high consumption of soft drinks among Australian secondary-school students. Public Health Nutr 2017;20(13):2340-8.

17. Vilaro MJ, Colby SE, Riggsbee K, Zhou W, Byrd-Bredbenner C, Olfert MD, et al. Food choice priorities change over time and predict dietary intake at the end of the first year of college among students in the U.S. Nutrients 2018;10(9). pii: E1296.

18. Stefańska E, Ostrowska L, Radziejewska I, Kardasz M. Sposób żywienia studentów Uniwersytetu Medycznego w Białymstoku w zależności od miejsca zamieszkania w trakcie studiów. Probl Hig Epidemiol 2010;91(4):585-90.

19. Wu X, Bastian K, Ohinmaa A, Veugelers P. Influence of physical activity, sedentary behavior, and diet quality in childhood on the incidence of internalizing and externalizing disorders during adolescence: a population-based cohort study. Ann Epidemiol 2018;28(2):86-94. 
20. Wattick RA, Hagedorn RL, Olfert MD. Relationship between diet and mental health in a young adult Appalachian college population. Nutrients 2018;10(8):E957.

21. Phillips E, Pojednic R, Polak R, Bush J, Trilk J. Including lifestyle medicine in undergraduate medical curricula. Med Educ Online 2015;20:26150. doi: 10.3402/meo.v20.26150.

22. Chung LMY, Fong SSM. Role of behavioural feedback in nutrition education for enhancing nutrition knowledge and improving nutritional behaviour among adolescents. Asia Pac J Clin Nutr 2018;27(2):466-72.

23. Currie C, Gabhainn NC, Godeau E; International HBSC Network Coordinating Committee. Health behaviour in school-aged children: WHO Collaborative Cross-National (HBSC) study: origins, concept, history and development 1982-2008. Int J Public Health 2009;54 Suppl 2:131-9.

24. Goldberg D. Kwestionariusz ogólnego stanu zdrowia GHQ-12-załacznik 2. In: Dudek B, editor. Ocena zdrowia psychicznego na podstawie badań kwestionariuszami Dawida Goldberga. Łódź: Instytut Medycyny Pracy im. J. Nofera; 2001.

25. Huebner -ES. Initial development of the Student's Life Satisfaction Scale. Sch Psychol Int 1991;12(3):231-40.

26. Htay SS, Oo M, Yoshida Y, Harun-Or-Rashid M, Sakamoto J. Risk behaviours and associated factors among medical students and community youths in Myanmar. Nagoya J Med Sci 2010;72(1-2):71-81.

27. Mazur J, Woynarowska B, Kołoło H. Zdrowie subiektywne, styl życia i środowisko psychospołeczne młodzieży szkolnej w Polsce. Raport techniczny z badań HBSC 2006. Warszawa: Instytut Matki i Dziecka; 2007.

28. Miller PM, Heideman PW, Ravenel MC, Spangler JG, Mauldin MP, Hill EG, et al. Preliminary development and evaluation of online tobacco and alcohol modules for dental students. J Dent Educ 2011;75(6):791-6.
29. Gawlikowska-Sroka A, Dzięciołowska E, Szczurowski J, Kamieńska E, Czerwiński F. Tobacco abuse and physical activity among medical students. Eur J Med Res 2009;14 Suppl 4:86-9.

30. Gawlikowska-Sroka A, Dzięciołowska-Baran E, Szczurowski J, Teul I, Poziomkowska-Gęsicka I, Kamieńska E. Cigarette smoking among students and the influence of legal regulations on passive smoking. Adv Exp Med Biol 2013;755:189-94.

31. Ostrowska L, Czapska D, Karczewski J. Ocena nadwagi i otyłości oraz nawyków żywieniowych studentów Akademii Medycznej w Białymstoku. Brom Chem Toks 2000;33(2):125-31.

32. Stroebele-Benschop N, Dieze A, Hilzendegen C. Students' adherence to dietary recommendations and their food consumption habits. Nutr Health 2018;24(2):75-81.

33. Winther A, Dennison E, Ahmed LA, Furberg AS, Grimnes G, Jorde R, et al. The Troms $\varnothing$ Study: Fit Futures: a study of Norwegian adolescents' lifestyle and bone health. Arch Osteoporos 2014;9:185. doi: 10.1007/ s11657-014-0185-0.

34. Al-Muammar MN, El-Shafie M, Feroze S. Association between dietetary habbits and body mass index of adolescent females in intermediate schools in Riyadh, Saudi Arabia. East Mediterr Health J 2014;20(1):39-45.

35. Nisar R, Qadri MH, Fatima K, Perveen S. Dietary habits and life style among students of private medical university Karachi. J Pak Med Assoc 2009;59(2):98-101.

36. Lipowicz A, Łopuszańska M, Kołodziej H, Szklarska A, Bielicki T. Secular trends in BMI and the prevalence of obesity in young Polish males from 1965 to 2010. Eur J Public Health 2015;25(2):279-82.

37. Conroy MB, Delichatsios HK, Hafler JP, Rigotti NA. Impact of a preventive medicine and nutrition curriculum for medical students. Am J Prev Med 2004;27(1):77-80. 